Article

\title{
THE MADNESS OF JODH SINGH: PATRIOTISM AND PARANOIA IN THE GHADAR ARCHIVES
}

\author{
ROHIT CHOPRA \\ Santa Clara University (Department of Communication, Associate Professor)
}

\begin{abstract}
This article centers on the experiences of Jodh Singh, a marginal figure in the history of the Ghadar movement, who exists as the sum of a few documents in official archives and the media record of the Hindu-German conspiracy trial of 1917-18 in which he served as witness. Based on a close reading of these materials, at the center of which is an official account of the insanity of Singh, I undertake an analysis of discourses of patriotism and paranoia in the archive. Making a case for viewing Singh as exemplifying the condition of subalternity, I describe how the juridical-legal-medical framework of the American state that condemns Singh is based on anxieties about madness, foreignness, and sexuality as threatening to the legitimacy of the state. I also argue that Jodh Singh's story offers the basis of a critique of the idea of the Ghadar Party as an exemplar of cosmopolitan values and solidarity, given that Ghadar discourse shares some assumptions with the state apparatus that has judged Singh as defective, guilty, and diseased. In undertaking such a reading, the article illustrates how the story of Jodh Singh troubles the distinction between patriotism and paranoia as it exists in the imagination of the state.
\end{abstract}

\section{Keywords}

Jodh Singh, patriotism, paranoia, sexuality, cosmopolitanism, foreignness, Hindu-German, madness, insanity, conspiracy

\section{Introduction}

Jodh Singh, prisoner of the US government, was insane. This was the unequivocal conclusion of the psychiatrists tasked with diagnosing him. Their diagnosis is included in the report of a commission appointed to evaluate Jodh Singh's physical and mental condition. Appointed on February 20, 1918, the Commission presented its report on March 12 of the same year.

Initially imprisoned at Alameda County Jail on November 27, 1917, Singh, according to the statement of the jail physician, was "apparently in the best of health and spirits" till February 14, 1918 ("Report" 1918, 13). On February 26, 1918, he was moved to a private sanatarium ("Report" 1918, 11). Medically, the report found Jodh Singh to be suffering from "prison 
psychosis" and syphilis. Legally, as well, he was determined to be insane. The Commission, accordingly, recommended that he should be institutionalized in a hospital for the insane.

Jodh Singh was a sympathizer with the cause of the revolutionary Ghadar Party. The aim of the party, founded in 1913 and based in the San Francisco Bay Area, was to foment a revolutionary armed struggle in India to throw off the yoke of British colonial rule. Led by intellectual elites, the party drew membership and support from the Indian labour diaspora in North America. Thoroughly internationalist in outlook, with a self-image that located the movement in a cosmopolitan genealogy of revolution against injustice, Ghadar members and sympathizers were part of a global network of political intrigue. In 1917, Ram Chandra, then leader of the Ghadar Party, other party members, and German diplomatic officials were arrested for planning a military conspiracy against the British, in violation of US neutrality laws. The trial of the Indians, Germans, and Americans accused of the conspiracy lasted from November 1917 to April 1918. Twenty- nine conspirators, Indian and German, were found guilty at what came to be known as the Hindu-German Conspiracy Trial. On April 23, 1918, a day before the trial concluded, Ram Chandra was shot by Ram Singh, a co-defendant in the trial.

Arrested in Bangkok by the Siamese government for "High Treason in connection with Hindu Conspiracy" plots, Jodh Singh turned informer for the US government ("Report” 1918, 4). He was first imprisoned in Bangkok, then in Singapore for 10 months, where he was brutally tortured (Special Correspondent 1917, 1-2; Smedley 1922, 341-42). Accompanied by Secret Service agents, he was taken to Chicago to testify in a case related to the plot in October 2017 and then to San Francisco (Smedley 1922, 341-42). In the Chicago trial, Jodh Singh indicated that he had turned witness for the US for fear of being tortured by the Indian Police (Special Correspondent 1917, 2). Yet, later, during the trial in San Francisco, on December 5, 1917, he claimed that he had been used as a pawn by both the British and the Americans ("Bomb Plots" $1918,7)$. Asking for his plea to be changed from "guilty" to "not guilty," Singh refused to testify, invoking in his plea America's legacy of justice and fairness by, among other arguments, comparing George Washington to a Mahatma or great soul ("Bomb Plots" 1918, 7; Smedley 1922, 342). Eventually placed in the Mendocino State Asylum in Talmadge in California, Jodh Singh was freed in 1921 thanks to the efforts of his father who had traveled to the US to find his son. "Mentally dead and physically ruined," he was taken back to India by his father (Smedley 1922, 342).

Representing what Ranajit Guha has called the "small voice of history," a source of historicity that is unrecognized by the implicit ideology of "statism" that marks disciplinary historiography, Jodh Singh exists as the sum of a few documents in official archives and special collections, media coverage of the trial, and scholarship on the Ghadar Party (1997b, 1). Through a close reading of a web of these documents and scholarly reflections, at the centre of which lies the report of the Commission appointed to inquire into his mental condition, I want to read the account of the madness of Jodh Singh as a statement about patriotism and paranoia.

A man broken by incarceration and violence, Jodh Singh also exists, in Guha's evocative phrase in another of his essays, as the "residuum of a dismembered past" (Guha 1997a, 37). Guha uses the term in the context of his analysis of an "untamed fragment" in the historical record, an 
account of the death of Chandra, a subaltern woman from among the most abject of social groups in colonial Bengali society (Guha 1997a, 37). Chandra's death results from a paste administered to induce an abortion that winds up killing her; the document in question is the testimony of members of the family about the event as recorded by a village scribe. In the essay, Guha argues that Chandra's death is already claimed by "two kinds of politics," seeking to "appropriate the event...as a discursive site-on behalf of the state in one case and on behalf of the community in the other" (Guha 1997a, 40). Guha's reading, a "critical historiography" that is both deconstructive and recuperative, is motivated by a profoundly humanizing desire: to view Chandra's death from the vantage point of a family struggling to deal with a crisis (Guha 1997a, 36, 40).

In a similar vein, I seek to understand Jodh Singh's trials as an individual's attempt to deal with repeated experiences of dislocation and violence. I am particularly interested in how the record of his experiences indicts the system that has judged him insane, that is, the juridical-legalmedical framework of American society. I also wish to examine how the figure of Jodh Singh points to the glimmers of a critique of the self-image of the Ghadar Party as a revolutionary movement committed to egalitarian principles. In undertaking such a reading, I am not aiming to demonstrate the 'truth' about Jodh Singh's madness, but rather to show how the story of Jodh Singh troubles assumptions about patriotism and belonging that are central to a reason of state. I also hope to illustrate how the figure of Jodh Singh might call into question a certain totalizing account of the Ghadar Party as an exemplar of cosmopolitan values and solidarity.

In my reading of madness as the site of a set of relations between the reason (and authority) of the state and society, my debt to Foucault's work on madness, especially his seminal text, The History of Madness, should be obvious (Foucault 2006). I draw on Foucault in my arguments about madness as the Other of reason (particularly a reason of state), of the social and historical construction of madness, and of the discourse of madness producing the very 'truth' that it seeks to find. In his introduction to the text, Khalfa points out that Foucault divides the separation of madness and reason into three phases, each associated with a distinct mode of social control (2006, $\mathrm{ix}-\mathrm{x})$. In the modern phase, which begins as the eighteenth century fades, madness is seen "as factual or positive, an object of science, as a disease or series of diseases" (2006, ix-x). The mad, that is those that are marked by this objective condition, are, consequently, deemed as legitimate objects of control, treatment, and confinement by a medical reason that is yoked to or subsumed within a reason of state.

It is to this modern phase that the experience of Jodh Singh belongs. But the madness of Jodh Singh must also be examined while taking into account the fact of another kind of difference, that of a treasonous foreignness, which threatens the very integrity of the state. Singh is doubly threatening: first, as the embodiment of the Other of reason that is madness and, secondly, as the foreign Other whose existence threatens the normative order of political and social life. The danger of foreignness represented by Singh is compounded yet further by his diseased sexuality, marked as the latter is by the symptoms of syphilis. Though Foucault is valuable in shedding light on the general link between madness and diseased sexuality, he does not say much about the specific threat that someone like Jodh Singh poses as the bearer of a racial and colonial difference that is 
also designated as sexually aberrant (Foucault 2006, 91). In seeking to understand what that threat might represent and what it may additionally illuminate about the juridical-legal-medical discourse on Singh, I draw on the work of Lowe and Shah who have critically examined the role of sexual and racial difference across various theaters and sites of colonial modernity (Lowe 2015; Shah 2011).

\section{Patriotism and Paranoia in the Ghadar Archives}

For its 'medical' diagnosis, the Commission found Jodh Singh to be suffering from three distinct ailments: "Prison Psychosis" with symptoms of paranoia, "Cerebro-Spinal Syphilis," and "Constitutional Psychopathic Inferior Individual" ("Report" 1918, 3). The last of these conditions, in turn, was "fertile soil for the development of the Psychosis upon a Neuro-Syphilitic basis" ("Report" 1918, 3). While the Commission expressed the view that symptoms of the psychosis could be managed, its 'legal' prognosis categorically described Singh as insane.

The report presents other traits, symptoms, and explanatory factors, which collapse medical and scientific diagnosis with social judgments and morality. Read a century later, the medical discourse reflects the prejudice of its age as much as it sheds light on possible causes for Singh's descent into insanity. Singh had in the last two years experienced nervousness, headaches, severe insomnia, and epileptic fits ("Report" 1918, 3). In terms of his personality, he was "secretly....Egotistical," "secretly revengeful," sarcastic, and "a Moody" individual" who was prone to contemplating suicide on occasion ("Report” 1918, 4-5). The 'Mental Examination' conducted on Jodh Singh highlighted his lack of hygiene, his destructiveness, an obsessive repetition of acts like washing his hands and the sink, the visual and auditory hallucinations that he experienced, his sense of persecution and paranoia, some weakness in memory, and his refusal to eat ("Report" 1918, 5-8). All these actions warranted that Singh be moved to a sanatarium in Oakland in California where he showed some improvement. His symptoms abated in intensity and he experienced "short periods when he [was] quite rational" ("Report" 1918, 7). Given the confirmation of insanity, the report absolved him of the possible charge of being a "Malingerer" or faking medical symptoms ("Report" 1918, 5-8).

In the narrative, the difference between Singh before and after the onset of his symptoms strikes one as stark. In his testimony at Chicago, for instance, Singh complained about not being allowed to bathe in Singapore. Incarcerated in a cell "full of vermin," Jodh Singh "testified that he had suffered great mental anguish because he was not permitted to bathe twice a day as his religion demanded (Special Correspondent 1917, 2). In contrast, in the report, Singh is described as "filthy in habits," urinating and defecating in his cell and then covering himself and walking in his waste ("Report" 1918, 6-7, 13).

The report presents us with a conundrum here. On the one hand, Singh's symptoms are consistent with a "syphilitic insanity," including delusions about persecution, thoughts of suicide, and violence, though Singh categorically denied having ever contracted syphilis when asked so for 
the report of the Commission ("Report" 1918, 41; Stewart 1870, 409-10). ${ }^{1}$ The account of Singh's symptoms is based on the statements provided by several individuals to the Commission. In a conversation with Mrs. M. Cowdrey, Matron of the Cowdrey Sanatarium, as recorded in her statement (which forms part of the report), Singh reported that "he felt queer for years" and had first experienced such feelings in 1912, suggesting that the symptoms of syphilis may have started manifesting themselves at this point ("Report" 1918, 18). Yet, on the other hand, the timing of the onset of insanity is curious, coming as it does right after Jodh Singh had possibly exhausted his value for the US government and had refused to be a witness for it. Through and after the duration of the trial in 1917, Jodh Singh was lucid, testifying as witness for the US government and clearly explaining the rationale for why he had first turned witness only to later retract his plea. All this transpired after Singh had already suffered torture during his imprisonment in Singapore. The report is silent about the fact that the "prison psychosis" suffered by Singh could have been a function of his current experience of incarceration at the hands of the government of the United States, as much as it could have resulted from his earlier spell in a prison in Singapore.

The document that designates Jodh Singh as insane speaks with both the objectivity of medical science and of the reason of the state. But the medical and legal diagnoses of Singh are inseparable from judgments that the report articulates about intrinsic moral character on grounds of nationality. Jodh Singh was deeemed to be suspicious "by personal make-up and nationality" ("Report" 1918, 4). According to the clinical psychologist, Mrs. Grace M. Hawkins, in her letter to one of the members of the Commission, Dr. Ball, Jodh Singh but naturally "talked peculiarly on account of his East Indian manner" ("Report"1918, 28). In the inquiry into Jodh Singh's condition, cultural difference, too, is coded as lack of reason. The statement of G.C. Denham, the chief of Indian Police Intelligence in Bengal, who had travelled to San Francisco in relation to the HinduGerman conspiracy plots, shows how the incomprehension of the questioning authority was projected on to the answering subject as a lack or deficiency within the latter (Plowman 2013, 10; "Report" 1918, 15-16).

He gave his evidence in the Chicago case...Seven men were executed and according to the record he said 'These men are my brothers' and so according to the interpretation, Jodh Singh caused the death of seven of his brothers. He didn't quite understand and he wanted to clear up the thing. They were not his brothers at all. Jodh Singh testified to the death of his seven brothers but it was just his way of speaking. They were not his brothers at all.

\footnotetext{
${ }^{1}$ The symptoms also seem to be consistent with one manifestation of neurosyphilis, namely General Paresis or what was termed General Paralysis of the Insane ("General Paresis" 2016; Hurn 1998, 6-7). Hurn, however, notes that the symptoms of GPI included "florid delusions of grandeur-in which the patient typically believed he owned everything around him-with a sordid physical decline" (Hurn 1998, 6-7). While the report amply details Jodh Singh's delusions, these do not qualify as delusions of grandeur. The term "General Paresis" is not used in the report itself.
} 
Curiously, for someone who was based in India, Denham seemed unaware of the idiomatic use of the term 'brother' or bhai, as a kindred spirit or fellow traveller in a cause. Again, the silence is instructive. The obvious explanation that Jodh Singh might be stricken by guilt at having betrayed his compatriots did not appear to strike Denham though he did pick up on Singh's agony over the decision. "Then he [Jodh Singh] asked to come over to this country. He came over and stayed some time in Canada, all the while tossing up whether it was right or wrong to give the evidence" ("Report” 1918, 15). Denham's statement ends with a revealing generalization: “They," that is the Hindus or Indians, "believe that all the world is an allusion and intangible," an instance when the prior knowledge possessed by official authority is simply confirmed by invoking it as explanation for Jodh Singh's actions and responses ("Report" 1918, 15).

The conflation of medical and legal judgment and the bleeding of moral judgment into the same may be explained by the fact that Jodh Singh, as an Indian immigrant, did not arrive into North America as an entirely unknown entity. Rather, Singh entered a social-political matrix powerfully shaped by ideas about racial and colonial difference in which the perception and reception of foreigners was structured by the deep-rooted anxieties and fears of the native population about the loss of jobs and the imagined physical, and often sexual, threat posed by the outsiders. Studies of the history of "transient male migration to North America" show that these migrants were seen "as a pernicious threat to democratic politics, economic distributions, and social morality" (Shah 2011, 13). Indeed, the very word 'Hindu,' which was used to describe Jodh Singh's identity in the report, carried with it the weight of such assumptions. As Shah notes, the term was an "axiomatic racial category codified in the 1911 Dictionary of Races created and used by the U.S. Immigration Service" that drew attention to the territorial source, Hindustan, of the migrants $(2011,14)$. The term functioned as a neutral descriptor for Punjabi migrants regardless of their religion but was also a slur or "derisive slang" $(2011,14)$. Shah points out that the South Asians who arrived in North America in the late nineteenth century and earlier were viewed primarily as exotic but unthreatening objects of fascination. However, with the influx of over 9,000 migrants into Canada in the first decade of the twentieth century, many of who would then move to the American Northwest, that image changed drastically. As with earlier waves of Chinese and Japanese immigrant labourers, South Asians were described in the rhetoric of infestation and invasion, deemed an economic and moral danger, and pathologized as a predatory sexual threat to white women $(2011,14){ }^{2}$ The turban worn by Sikh migrants became a highly visible symbol of cultural and civilizational difference. Viewed as dirty, barbaric, and incompatible with Western modes of dress, the turban functioned as a "a marker of the unsanitary and the disordered as well as the exotic alien," concatenating a range of associations about racialized Otherness $(2011,39)$.

The social, political, and economic structures that informed such reactions were themselves embedded in the broader logic and longer histories of liberal colonial governmentality, which, as Lowe has shown, was predicated on the control, regulation, and dominance of the bodies of the

\footnotetext{
${ }^{2}$ See Shah, pp. 19-30, for a description of the prejudices against South Asian migrants arriving in North America and the violence that they faced.
} 
colonized (2015). Lowe argues that as Britain expanded its territorial possessions in the nineteenth century, colonial power began to operate in both 'negative' and 'positive' capacities $(2015,102)$. As negative force, colonial power could "seek, enslave, occupy, and destroy" as it had in colonial Hong Kong and elsewhere $(2015,102)$. However, colonial power also manifested itself in a "new mode of imperial sovereignty" that would "administer the life, health, labour, and mobility of colonial bodies" $(2015,102)$. Examining the logic of colonial governance and the Anglo-American politicaleconomic order in China and Hong Kong in the wake of the Treaty of Nanjing that brought the first Opium War (1839-1842) to an end, Lowe describes how a vastly expanded set of regulatory and disciplinary powers over restive and potentially dangerous populations became not just compatible with but indeed central to a notion of liberal government $(2015,110)$. The state drew a distinction between its own "'legitimate' violence against the threat of 'illegitimate' violence from others it deemed criminals, dissenters, and disturbers of the 'peace"” $(2015,110)$. This distinction entailed the pathologization and criminalization of a disenfranchised diasporic Chinese population in Hong Kong, that would then migrate again to work as labour across the globe.

In demonstrating how colonialism operated as a productive force, Lowe provides us with a set of rich insights into the historical, political, and economic forces that would have shaped the journey of someone like Jodh Singh. Singh's entry and participation in the Ghadar movement was itself partly a product of these forces and partly an act of a resistance to them, born as it was of the colonial encounter between Britain and India. His arrest, interrogation, treatment in prison and in the sanatarium, on the other hand, can be seen as consistent with the assumptions of liberal colonial government detailed by Lowe above. These assumptions also underpinned the juridicalmedical-legal framework which had locked Jodh Singh into its gaze; they were reinforced here by America's own founding history of violence, its legacies of prejudice against South Asians, and the role that the American state played as proxy for British colonial power in its treatment of Singh.

These foundational assumptions surface not just in the generalizations about nationality and race made in the report of the Commission, but also in the report's strained attempt to assess Jodh Singh as a singular, distinct individual. The report's struggles to pin down and fix Jodh Singh are instructive in at least two critically important respects. One, they help us grasp a particular sense in which we can see Jodh Singh as a subaltern figure, sharing the condition of the 'small' voices of history I have mentioned earlier. And two, these struggles show how colonial knowledge is bedeviled by guilt and uncertainty about its own assumptions about colonized subjects.

The report makes several assertions about Jodh Singh's passivity, stating that Singh's "extreme altruistic ideas" render him a "dreamer", used here in the sense of someone incapable of independent action ("Report" 1918, 4). Describing Singh as always "content...to assume an inferior position but wishing great things," the report avers that he is clearly not a leader but an eternal follower ("Report" 1918, 6). Yet the report struggles to make a comprehensive case for Singh's constitutional inabilities, for, despite his troubles and seemingly obvious defects, his qualifications and achievements are not explained away so easily. A speaker of five languages, Singh had also studied electrical engineering ("Report" 1918, 4). While he did not display any ideas of "Dominence" ("Report" 1918, 5), presumably meant to refer to significantly original thoughts, 
he had shown "Initiative... as regards his own intellectual development" ("Report" 1918, 5). Under the category of 'Personality', the report states that Singh's "ideation processes are good" and considers his ability to express ideas "up to the time of his incarceration in the Alameda County Jail, and shortly thereafter" as very good ("Report" 1918, 5). The results of the "Mental Examination', in contrast, detail Singh's “Abnormal Ideation” as reflected in his diary and interviews. If his personality, based on his remarks, is categorized as "possibly that of a homosexual type" ("Report" 1918, 5), Singh has also testified that "he liked them [women] very much" ("Report" 1918, 5). The report cannot find an external source of some of Singh's failures although it suggests that circumstance has played some role in bringing him to his current situation. Ultimately, though, it is Singh's failure to lead, think for himself, or to overcome his internal shortcomings that are found responsible by the report for his predicament. The same reasoning also informs the finding that Singh is a Constitutional Psychopathic Inferior Individual.

The category of Constitutional Psychopathic Inferior Individual is already a condemnation, predicated as it is in part on an ultimately opaque conception of nature or character that is taken as a basis for aberrant behavior. Yet, as a medical and scientific judgment, it has already claimed an objective status for itself. A study of the condition from the general time period lists "emotional irritability" as one of its symptoms, attributing it to "perverted emotions" (Orbison $1929,78)$. Orbison describes it in the following manner:

Constitutional Psychopathic Inferior personality (C. P. I) is an inherent constitutional condition which is the basis of personality, for the reason that it represents the sum of psychic elements of that individual. These elements are exhibited objectively in every case, in terms of pathological behavior, of that individual.

It is not a disease and is therefore not curable. Being a constitutional fault it may be corrected, but only by such means and methods as are capable of supplying psychic stability by the engrafting of normal acquired character factors...(Orbison 1929, 78).

The language of intrinsic defect is emphasized elsewhere in this text as well. Constitutional psychopaths suffer from "inherent instability" (Orbison 1929, 79). Their "inherent perversion," as well as the fact that they do not necessarily lack intellectual competence, is precisely what makes them highly dangerous to society, more so than the "insane or feeble-minded" (Orbison 1929, 80). And it is, consequently, the duty of the state to respond to this threat much as it does to natural disasters or riots (Orbison 1929, 80-81).

There are, then, at least three discourses that have already prejudged Jodh Singh in one respect or another:the discourse of liberal colonial governmentality, the discourse of the racialized Other in early twentieth century America, and the medical discourse of inherent inferiority. To this we can add a fourth discourse, that of the sexually aberrant, given that Singh is confirmed as 
suffering from syphilis and is also defined as a possible "homosexual type" ("Report" 1918, 5). Foucault points out that from the classical age, roughly the seventeenth and eighteenth centuries, sexuality had been brought under the same rubric as madness in one vital respect:

When the classical age locked up those who through sexually transmitted diseases, homosexuality, debauchery or prodigality had demonstrated a sexual freedom that previous ages might have condemned but had never dreamt of assimilating to insanity, it brought about a strange moral revolution, uncovering a common denominator of unreason among experiences that had long remained separate from each other. It banded together a whole group of blameworthy behaviour patterns, creating a halo of guilt around madness (Foucault 1990, 91).

As is the case with madness, sexuality then became a legitimate object of intervention, a zone to which the technologies of biopolitics could be applied to individual bodies and populations for purposes of domination as well as treatment and experimentation. Indeed, as Foucault argues, according to the science of sexuality that emerged by the nineteenth century in Western societies, "sexuality was defined as being 'by nature': a domain susceptible to pathological processes, and hence a calling for therapeutic or normalizing interventions," even as it was understood as an area of darkness that had to be parsed into legibility $(1990,68)$. And, as Shah (2011) and others have shown, if sexuality is viewed as a subversive force that must be brought under the control of political-bureaucratic order in the imagination of the modern state, the sexuality of the foreign body is even more subversive.

As condemned on not just one but several grounds, Singh may be considered as exemplifying the condition of subalternity, even if he is not an immediately recognizable or 'classic' subaltern figure like a peasant, tribal, or a member of a marginalized caste, or group lacking caste. As the subject and object of a knowledge, indistinguishable from an ignorance ordained by the American state that had already authorized a violence against him, Singh embodies the vulnerability and abjection that are the hallmarks of subalternity. In delineating the multiple genealogies of the Subaltern Studies movement, drawing as it does on Marxism, poststructuralism, and postcolonial theory, Prakash suggests that to speak of-or to even try and identify-an authentic subaltern consciousness or a set of defining characteristics of the idealized subaltern subject might be a profoundly misguided venture. "The subaltern," Prakash notes, "is a figure produced by historical discourses of domination" $(1992,8)$. While "the early phase of the Subaltern Studies was marked by a desire to retrieve the autonomous will and consciousness of the subaltern," the movement later abandoned "this desire to recover the subaltern's autonomy... because subalternity, by definition, signifies the impossibility of autonomy" (Prakash 1992, 9). Prakash goes on to articulate a set of relations between the state of subalternity and structures of power, arguing that to be subaltern, as it were, is to to be subject to hegemonic discourses, whether those of the nation-state, modernity, science and technology, or forms of instrumental reason (1992). I propose that by this yardstick and definition, we can meaningfully 
see Jodh Singh as reflecting the condition of subalternity. In fact, as I will now argue, the discourse of revolution espoused by the Ghadar Party also operates as a hegemonic discourse with regard to him, locating Singh, as it does, in a relative condition of subalternity.

In the report of the Commission, the apparatus of the prison and sanatarium represent the state as the counterpoint to Jodh Singh who is accused of "High Treason" against it ("Report" 1918, 4). Here the discourse of the report stands in an ambivalent relationship to the discourse of the Ghadar Party. For the Ghadar Party, India and the US were natural allies, both sharing a history of anticolonial revolution. It is this belief, arguably, that prompted the members of the Ghadar Party to openly call for armed revolution in India and that possibly explains its silence on the question of racial discrimination within the United States.

When it comes to class, though, Ghadar discourse is messier and riven by contradictions. Juergensmeyer argues that class issues were significant in the initial phase of the movement, when meetings in Oregon 1912 and 1913 "were concerned with labour issues as well as nationalism" $(1977,9)$. However, as the movement took shape in San Francisco, it included in its fold students, intellectuals, and farmers from varied economic backgrounds, including landowners as well as labourers who did not own property (1977, 9-10). According to Juergensmeyer, these issues did not create any discord among Ghadar members $(1977,10)$. He sees the movement till 1918 as "exclusively nationalist, with a touch of utopian socialism" $(1977,10)$. In contrast Ramnath, in a more recent work on the radical legacies of the Ghadar movement, views it as animated by concerns broader than a narrow nationalism, drawing attention to the "members' own expansive universalist principles" $(2011,4)$. I want to suggest, however, that in one important respect, perceptions of class among the more privileged segments of the Ghadar movement occupy the same discursive field as the medical and psychiatric-legal authorities that constitute the Commission to assess Jodh Singh-the idea of the rank-and-file member of the movement as incapable of independent agency.

For the authors of the report, Jodh Singh, despite having had the opportunity to meet people of all classes and backgrounds in several countries had only acted upon the directions of others ("Report" 1918, 4-5). In a talk given at the University of California Berkeley in 1973, nearly three decades after the voluntary formal disbanding of the Ghadar Party following India's independence in 1947, Gobind Behari Lal, who, in his own words, "had some thing to do with the initiating of the GADAR EXPERIMENT," provides us with a sense of the movement's understanding of the relationship between its leaders and members (1973, 1, capitals in original). The 23-year old Lal, a student at the university, had called a meeting in 1913 to express support for an Indian Maharaja's initiative of establishing a parliament for the purpose of governance (1973, 2). Lal describes the Ghadar "experiment"itself in strong class terms:

What kind of an experiment was THE GADAR? It was based upon a theory, which had to be tested by a test. Crudely stated the theory was even that the pre-learned Indians can be instructed politically, and become motivated by modern freedom. The idea of self-government, which is political freedom, can be transmitted from 
the learned to the unlearned common people, farmers, factory and other sorts of routine workers and so forth $(1977,3)$.

Lal goes on to claim that Har Dayal, the leader of the Ghadar Party at the time, was very successful in carrying out this experiment, significantly "changing nonpolitical Indian minds," and that the Ghadar experiment "perhaps prepared the way indirectly, for the Great Gandhi Experiment" that led to India's freedom $(1977,3)$. For Lal, the Indian masses lack political agency by virtue of being pre-political and are "pre-modern in their cultural experiences" (1977, 3). Jodh Singh did not belong to the peasant classes, but could fall into the category of "routine workers" that Lal describes $(1977,3)$. The report notes that Jodh Singh was educated in India from "a clerical and commercial standpoint," though later he attained some knowledge of electrical engineering ("Report" 1918, 3). Clearly, though, Jodh Singh was not part of either the intellectual vanguard or the political leadership of the Ghadar movement. For the authors of the report of the Commission, Jodh Singh lacked in agency because of individual failings of character, which constitutionally ruled out any political independence and intellectual autonomy on his part. For the intellectual leaders of the Ghadar movement, it was Jodh Singh's background that rendered him disadvantaged with regard to any kind of sophisticated political understanding. The difference, though, is that for the Ghadar leadership, Jodh Singh's consciousness was nevertheless capable of being politically charged to the extent of enabling participation in the movement toward the grand goal of securing Indian independence.

The report also strains to persuade us of the illegitimacy of Jodh Singh's nationalism. We can read the report here as betraying an anxiety about distinguishing Jodh Singh's nationalism and patriotrism to the cause of Indian independence from its own service in the cause of patriotism to the United States. As with the question of Jodh Singh's abilities, the report attempts to resolve these contradictions and tensions through explanations founded on a predetermined knowledge that assumes the status of objective reason. According to the report, Jodh Singh has "innate 'crooked' tendencies" which he seeks to justify through the invocation of patriotism, or, "which he excuses to himself on the grounds of personal uplift (educationally) for the furtherance of his altruistic ideas for the national benefit_to him a justifiable means toward an idealistic end" ("Report" 1918, 4). Jodh Singh's lack of agency is described in the report as undermining the purpose of his actions; he is described as someone who has merely been carrying out orders without understanding their import.

Singh, for the authors of the report, dreams "dreams for his people" but these dreams are tinged with impotence, the sterile fantasies of someone who cannot act of his own accord ("Report" 1918, 5). C.E. Curdts, the physician at Alameda County Jail, presents to us a revealing account of one such fantasy. Singh insisted that his cell was the "center of India" and that four men had visited it. The ring leader among these was "trying to become the 'King of England' and another of these men was trying to become "King of India"” ("Report" 1918, 13). In this fantasy, we can perhaps see the glimpses of a kind of reason in expressions of Singh's conflicted self; his being, for which his cell can serve as metaphor, has become the theater of a conflict between Britain and India for 
political supremacy. But this oblique expression of nationalist sentiment, rendered in traces, already lacks legitimacy for on account of Jodh Singh's nationality, background, personality and madness.

Contrast this to what, from the perspective of the law and reason of the American state, are considered the legitimate nationalism and patriotism of Americans. Following the uncovering of the plot and the arrests of those accused in the conspiracy plot, J.W. Preston, US Attorney General, began an elaborate procedure of gathering evidence for the trial. There is a particular kind of document in his archives that is of interest for my purposes here. The archives feature a number of letters from concerned citizens writing in to the authorities and reporting on the suspicious activities of Germans, Hindus, and others.

Replying to a Mrs. James Tucker, the US Attorney thanks her for providing the address "of the young lady in Berkeley from whom we might obtain certain information about the Americanism of the President of the University" ("Correspondence to Mrs. James E. Tucker" 1917). A telegraph operator, John Hilliard, writes, with apparent worry, to Preston, in response to the news of Dr. A. Farid, an Egyptian, being arrested in connection with the conspiracy, to clarify the fact that he recently had a conversation with Farid but was unaware of the latter's link to "Hindu plotters" (“Correspondence to John W. Preston from John Hilliard” 1917). Mr. R. R. Lucas, who owns an auto supplies business of the same name, presents the following request to Preston: "Would I be intruding on your or your office by suggesting that you quietly have the past, present, and future conduct of one of our prominent German friends of Maricopa investigated?" (Correspondence to John W. Preston, U.S. District Attorney, San Francisco from R.R. Lucas 1917). A letter to Don Rathbun, a special agent of the Bureau of Investigation, from the US Attorney details a Mr. Palmer calling in about his Philippine neighbor, who has had "a dozen or so more very probably Germans" visiting his house ("Correspondence to Don S. Rathbun, Special Agent, Bureau of Investigation from U.S. Attorney, 3/28/1917” 1917). Preston also invokes the idea of patriotic duty that is expected of American citizens. In response to a query from R. A. McNally, the city editor at the Honolulu Star-Bulletin about a German official arrested in the plot, Preston states that duties preclude him from responding to McNally's questions in detail (“Correspondence to R.A. McNally, 1917”). Preston ends the letter by raising the specter of loyalty-"I assume from the tone of your letter that you are in sympathy with the prosecution of those who are conspiring to violate the laws of the United States" - that also sounds very much like a threat (“Correspondence to R.A. McNally, 1917”).

These are some voices of 'suspicious' American citizens, the very trait attributed to Jodh Singh as a defect that is rooted in both his East Indian nationality and Hindu ethnicity and linked to his servility and sullenness. Along with fears of foreignness, the letters also enunciate a demand that Americans should prove their loyalty to the state by constantly performing and demonstrating their patriotism. Nationalist loyality is an especially dangerous commodity: its presence and existence has to be continually proved and asserted as an article of faith. Reframed as vigilance motivated by loyalty to America, suspicion and anxiety rooted in nationalist sentiment appear as entirely positive virtues in the letters that Americans write to the officials who are the 
representatives and bearers of state reason. In Jodh Singh's cell, which, in one of his delusions, he described as the center of India, however, suspicion and anxiety are incontrovertible proof of paranoia. Decontextualized and delinked from the service of the state, the performance of nationalism is simply illegible, incoherent madness.

\section{Conclusion}

Was the Ghadar movement itself, too, a kind of madness? From the vantage point of the present, in which the surveillance capacities of the modern state have been amplified manifold, it seems remarkable that a movement like Ghadar could have even happened. If its aspirations seem unrealistic in a time when our political imaginations cannot grant a legitimate place to the utopian, consider that for a long time the members of the Ghadar Party were able to get away in the United States with openly calling for armed insurrection against the colonial British government. They also found support in Irish-American and other American groups, who shared their antipathy to the British and to colonialism. Perhaps, those who lived in that historical moment, inhabiting international networks of political solidarity committed to radical political change, would have seen our times as beset by a kind of madness.

Whatever it was-an expression of radical cosmopolitanism, an experiment, or a unique madness - the movement depended upon the labour, energy, and affective investment of countless individuals, some of whom gave their lives for the movement or, like Jodh Singh, were destroyed by it. Singh's account provides testimony of the cost of this commitment, the collateral damage masked by the narratives of the Ghadar Party either as treasonous conspiracy against colonial Britain and the US, an anticolonial nationalist project, or a radical socialist or communist project. In aiming to listen to Singh's voice, within and beyond the experience of madness, I have tried to employ empathy as a methodological imperative, to question the violence of not just the reason of the state, but also of the political aspiration of the Ghadar movement. It is not just the liberal state but also radical movements that purportedly aspire to the same ideals of equality and freedom that consume the Jodh Singhs of the world, with their lives being spoken for and assimilated in the service of the grand narrative of one or the other.

As a final thought, it is appropriately ironic that Jodh Singh should have been diagnosed by "alienists," a term used to describe the psychiatrists operating in a legal capacity ("Report" 1918, 3). For the term "alienist," an archaic word for "those who study the insane" and etymologically derived from the Latin for the "Other," carries with it the sense of the outsideness of the immigrant and of the estrangement of those exiled by history and circumstance. And inasmuch as alienation itself can be seen as an Other of solidarity, the tragedy of Jodh Singh can be read as a cry for solidarity - a solidarity that, in the ultimate analysis, he did not find either in the Ghadar Party or in American society. 


\section{References}

“Alienist.” Merriam-Webster. http://www.merriam-webster.com/dictionary/alienist, (accessed August 4, 2016)

“Bomb Plots.” January 30, 1919. The Evening Post. 7.

"Correspondence to Don S. Rathbun, Special Agent, Bureau of Investigation from U.S. Attorney, 3/28/1917." 1917.

“Correspondence to Mrs. James E. Tucker from U.S. Attorney, 12/17/17.” 1917. Box 1, Record Group 118, Records of The Office of the U.S. Attorney, Northern District of California, Neutrality Case Files, 1913-1920. National Archives and Records Administration-Pacific Region (San Francisco).

“Correspondence to John W. Preston from John Hilliard, 12/14. 17.” 1917. Box 1, Record Group 118, Records of The Office of the U.S. Attorney, Northern District of California, Neutrality Case Files, 1913-1920. National Archives and Records Administration-Pacific Region (San Francisco).

"Correspondence to R.A. McNally, City Editor, Honolulu-Star Bulletin from U.S. Attorney, 9/11/1917." 1917. Box 1, Record Group 118, Records of The Office of the U.S. Attorney, Northern District of California, Neutrality Case Files, 1913-1920. National Archives and Records Administration-Pacific Region (San Francisco).

Foucault, Michel. 2006. History of Madness. Jean Khalfa, ed. Jonathan Murphy, trans. $1^{\text {st }}$ edition. New York: Routledge. 1990. The History of Sexuality. Volume I: An Introduction. trans. Robert Hurley. New York: Vintage Books.

“General Paresis.” 2016. MedlinePlus. U.S. National Library of Medicine, U.S. Department of Health and Human Services National Institutes of Health, last updated August 1, 2016. https://medlineplus.gov/ency/article/000748.htm (accessed August 12, 2016)

Guha, Ranajit. 1997a. “Chandra's Death.” In his, ed. Subaltern Studies Reader, 1986-1995, pp. 3642. Minneapolis: University of Minnesota Press. 
. 1997b. "The Small Voice of History." In Shahid Amin and Dipesh Chakrabarty, eds., Subaltern Studies: Writings on South Asian History and Society, Vol. 9, pp. 1-12. Delhi: Oxford University Press.

Hurn, Juliet D. 1998. “The History of General Paralysis of the Insane.” PhD thesis.

Juergensmeyer Mark. 1977. “The Ghadar Syndrome: Nationalism in an Immigrant community." Punjab Journal of Politics 1: 1-22.

Lal, Gobind Behari. May 9, 1973. “The Gadar-at U.C. Berkeley: Thoughts Presented by Gobind Behari Lal." South Asians in North America Collection, BANC MSS 2002/78 cz, The Bancroft Library, University of California, Berkeley.

Lowe, Lisa. 2015. The Intimacies of Four Continents. Durham, NC: Duke University Press.

Orbison, Thomas J. 1929. "Constitutional Inferior Pyschopathic Personality-With or Without Psychosis." California and Western Medicine 30 (2): 78-83.

Plowman, Matthew Erin. 2013. “The British Intelligence Station in San Francisco during the First World War." Journal of Intelligence History 12 (1): 1-20. DOI: $10.1080 / 16161262.2013 .755016$

Prakash, Gyan. 1992. "Postcolonial Criticism and Indian Historiography.” Social Text 31/32, Third World and Post-Colonial Issues: 8-19. DOI: 10.2307/466216

Ramnath, Maia, 2011. Haj to Utopia: How the Ghadar Movement Charted Global Radicalism and Attempted to Overthrow the British Empire. Berkeley, California: University of California Press.

"Report of Commission...to inquire into the mental condition of Jodh Singh, A United States prisoner. March 12, 1918.” 1918. Box 5, Record Group 118, Records of The Office of the U.S. Attorney, Northern District of California, Neutrality Case Files, 1913-1920. National Archives and Records Administration-Pacific Region (San Francisco).

Shah, Nayan. 2011. Stranger Intimacy: Contesting Race, Sexuality, and the Law in the North American West. Berkeley, CA: University of California Press.

Smedley, Agnes. 1922. “Jodh Singh.” The Nation 114 (2959): 341-42. 
Socialist Studies / Études socialistes 13 (2) Fall 2018

Special Correspondent. October 17, 2017. “Tells How Plots Were Hatched.” The Milwaukee Journal: 1-2.

Stewart, H. Grainger. October 15, 1870. "Syphilitic Insanity.” The British Medical Journal : 409-10. 